\title{
Construction of College English Translation Teaching Model in the Context of Information Technology
}

\author{
Qian Lu \\ Jiangxi Police Institute \\ Nanchang 330103 China
}

\begin{abstract}
In the teaching of college English, English translation teaching can not only reflect the translation level of college students, but also a reflection of college students' ability to learn English. Therefore, it is important to say that the status of college English translation teaching in college English teaching is important. Teachers and schools should pay attention to English translation teaching and provide more teaching methods and resources. The ability of college students to trans late English can be improved effectively. In this paper, it is a good opportunity for university English translation teaching to make full use of information technology. This paper analyzes the construction of English translation teaching mode in the information technology environment, and points out the innovation of English translation teaching in the information technology environment, and promotes the improvement of college English translation te aching.
\end{abstract}

Keywords-information technology; College English translation teaching

\section{SHORTCOMINGS OF COLLEGE ENGLISH TRANSLATION TEACHING}

In the past college English translation teaching process, the teaching mode generally lacks a kind of innovative thinking. This kind of innovative thinking is mainly reflected in the traditional teaching mode in the past college English translation teaching process. That is to say, the teacher's explanation in the classroom is the main subject, and the students passively accept the content of the teacher's explanation. In such a teaching mode, teachers usually only pay attention to the final result of teaching translation. That is to say, teachers master students' learning effect from students' translation in the homework. For students, they only passively accept what the teacher has explained, and cannot think and innovate well. In addition, for this traditional teaching model, what the teacher has explained is only the translation theory and some skills, and there is no training on students' vocabulary, sentences and other language abilities. There is also a lack of communication and interaction between teachers and students. Such teaching effect will make students lack certain initiative in learning, and it is also very unfavorable to the cultivation of students' language ability. Therefore, students' practical ability cannot be improved in college English translation teaching.

There is also a common problem in college English translation teaching, which is that the translation textbooks used by schools are relatively old and antiquated. It cannot be updated in time. At present, in view of the college English translation textbooks adopted in many universities, a common problem is that the use of college English translation textbooks is relatively aging. These textbooks cannot keep up with the pace of the development of The Times in terms of the content update and the speed of the publication of the textbooks. Without certain innovative contents, they cannot be closely combined with the progress of The Times in terms of the content and the speed of publication. Then, there is a very real problem: English teachers in college English classroom teaching, the main basis is the teaching materials used. If the English textbooks cannot be updated in a timely manner, the teaching contents conducted by English teachers cannot be well integrated with The Times, nor can students be closely improved in practical application after learning. Therefore, students do not have a strong interest in English translation, which is not conducive to the improvement of students' English translation ability.

In the process of college English translation teaching, there is a general problem that the time of English translation teaching is relatively short, and the number of hours is relatively small. From the current situation of college English translation teaching, many colleges and universities have very little time arrangement for college English translation teaching, which is far from enough to meet students' needs for English translation learning. In addition, under the current teaching mode, some schools only set English teaching to cope with exams and the examination of the higher authority education department, but not to improve students' English translation ability. Therefore, it is fundamentally determined that neither teachers nor students can get enough attention to the study of English translation. At the same time, we all know that learning English requires a certain language environment, both in and out of class. Therefore, if there are few classes for English translation, students will be deprived of the edification of the language environment, which is a very important factor, which will affect students' effect on English translation and overall learning quality.

Most colleges and universities have a relatively simple way of evaluating English translation teaching, and they can't be evaluated by the individual differences of students. At present, the university's English translation teaching evaluation system is often relatively single, and many schools still use the 
traditional method of testing education for English translation teaching. They are mainly based on the students' written test results in the exam, thus evaluating the students' effect on English translation. The consequences of this do not only be a one-sided assessment of the ability of students to translate, and they cannot make a comprehensive evaluation and evaluation of the students' oral and practical applications. At the same time, for every student, students have different individual differences. In the course of English translation teaching, the traditional teaching mode of the past is often only adopted in the unified teaching method, and it is not possible to make reasonable design teaching methods for each student's individual differences. This makes the individual difference of the students insufficient enough to be paid attention to, just as the result of the examination as a translation. The effect of this is not ideal, nor does it improve the students' interest in active learning, which can cause some big adverse effects on the students' ability to translate.

\section{ADVANTAGES OF USING INFORMATION TECHNOLOGY IN} COLLEGE ENGLISH TRANSLATION

Teaching the application of information technology in college English translation teaching can greatly promote and complement the traditional English translation teaching, expand and enrich the teaching methods of college English translation, and stimulate students' interest in learning English translation. With the continuous development of society, information technology has been widely used in all walks of life. In school teaching, multimedia tools based on information technology development can be widely used in the teaching of various subjects. The wide use of multimedia teaching tools based on information technology in the classroom can completely change the traditional teaching mode. It changes the previous single and boring teaching mode, so the application of multimedia teaching technology in the classroom can make the courses taught by teachers very rich, lively and interesting use of multimedia animation, audio, video, pictures, etc. to be displayed in the classroom. In this way, the on-site teaching atmosphere is livelier, and the teaching content can be expanded. In this way, students' active initiative in learning in class can be greatly stimulated, thus enhancing their interest in learning. The use of information technology can bring great innovation to the classroom teaching methods and create corresponding teaching situations in the classroom, so that students can be easily integrated into the English translation teaching environment.

The application of information technology in college English translation teaching can greatly improve the quality of translation teaching and improve students' independent learning ability. With the continuous development of information technology, translation teaching is no longer limited to on-thespot classroom teaching. Translation teaching can also be applied in students' extracurricular learning. The development of information technology has promoted the development, implementation and application of many auxiliary teaching tools, and various translation tools have been developed. By applying these tools to English translation teaching, we can improve the quality of teaching and the efficiency of teaching. For many translation tools, these tools store a lot of language material. Through these information technology-based multimedia teaching tools to display the database of language materials, the teaching efficiency of college English can be improved. At the same time, college English translation teaching based on information technology can also help students acquire more information and knowledge, improve students' ability to solve problems and apply knowledge, and guide students to learn independently.

\section{CONSTRUCTION OF COLLEGE ENGLISH TRANSLATION TEACHING MODEL IN THE CONTEXT OF INFORMATION TECHNOLOGY}

Information technology optimizes classroom teaching contents through information technology. Based on the analysis of the current college English teaching situation, in most colleges and universities, during the college English teaching, most non-English majors did not take English translation teaching as a key teaching content for training. Therefore, in the whole college English teaching, the proportion of English translation is very small. According to relevant research, English translation is very important for improving students' English ability, and it can also quickly improve students' English ability. Therefore, in college English teaching, both schools and teachers should pay more attention to English translation teaching, and English translation should increase class hours and corresponding time in the whole college English learning process. However, in college English classes, because students have to learn more subjects, English teaching does not necessarily add too many hours to English translation. Therefore, when learning English translation courses, English teachers should carefully select the translated content and choose some classic paragraphs, so that students can better understand the translation skills and knowledge of the selected paragraphs within the limited translation time. At this time, if the English teacher can optimize the content he teaches through information technology in the English translation class, then it can improve the teaching quality of the teacher and the learning effect of the students. For example, in English translation class, teachers can play some classic English movie clips to students through multimedia, and then ask students to express the content of the movie in Chinese, and vice versa. In the classroom of English translation, teachers can make full use of the advantages of information technology, and try to stimulate students' interest in learning by making use of some multimedia materials such as video and pictures, so that students can keep up with the pace of the teacher's teaching in class, thus improving students' efficiency.

We should make full use of the information technology to achieve the construction of college network teaching platform. Modern information technology can be widely used in many fields, because information processing technology has strong data processing capacity. This is also a great help for English translation teaching. English teachers can make full use of information processing technology and upload the content that they have no time to teach in class to students through the Internet for downloading after class for further learning. At the same time, we can also store some lectures delivered by the teacher in class on the network through the network cloud technology, so that students can further learn and understand 
by playing back what they have not understood in class. In addition, under the strong technical support of information technology, teachers can also build an online teaching platform, where students can be tested on English translation, and establish communication and interaction with students. Allows students in the learning problems reflected in the network teaching platform, and then by English teachers to answer questions to the student, so that it can be very good to promote the interaction between students and teachers, to break the time and space constraints, so that students of English translation study with more interest and initiative. Building a network teaching platform, the teacher can at any time through the computer to the real-time English translation test to the student, and real time grasp the learning situation of students, so that it can bring more flexibility to the students' learning, but also conducive to through the computer information processing technology to students learning a large data analysis, thus is advantageous to the teacher found that students who study in English translation problems, and then targeted guidance.

We make full use of information processing technology in the evaluation system of English translation. As for the assessment of students' learning of English translation, generally speaking, the test of English translation ability in China still adopts the traditional test method, which usually only tests students' exam-oriented ability, while the examination of students' comprehensive ability is relatively rare. In English translation ability of students is evaluated, if we can make good use of information technology, it can be anywhere at any time to master the translation ability of students, and through various forms of test for students to learn whether the network teaching platform has a more objective understanding, thus for students' learning situation can also learn some more data for analysis. At the same time, students can make full use of the information technology to achieve self-detection and have a timely understanding of their own learning situation and find problems, which will be more effective than traditional exam-oriented tests. At the same time, students can also choose appropriate translation test questions according to their major to answer questions, which is not the same type of paper test paper.

\section{CONCLUSION}

All in all, college English translation teaching must be paid attention to by schools and teachers. We should enable students to improve the comprehensive ability of college English listening, speaking, reading and writing in the process of translation. We should also make full use of information technology to improve the quality of college English translation teaching so as to improve students' English translation ability.

\section{REFERENCES}

[1] Research on problems and countermeasures in the context of secondary vocational English teaching in the context of information technology [J]. Li Huiling. Education, China off-campus.2017(04)

[2] English teaching strategies for secondary vocational schools in the context of information technology [J]. Zhang Haiqin. Technology information.2016(27)

[3] Professional development of college English teachers based on microteaching in the information technology environment [J]. Hao Yajie. Education technical equipment in China.2011(36) 